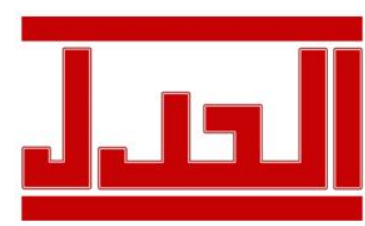

ISSN: $1979-4940$

E-ISSN: 2477-0124
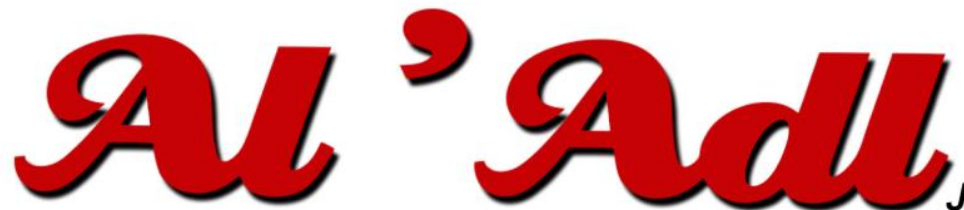

Jurnal Hukum

Editorial Office: Faculty of Law, Islamic University Of Kalimantan,

Jalan Adhyaksa No. 2 Kayutangi Banjarmasin, Kalimantan Selatan, Indonesia (70123)

Email: al_adl@uniska-bjm.ac.id

Web: http://ojs.uniska-bjm.ac.id

\title{
PERSPEKTIF HUKUM TERHADAP UPAYA ANTISIPASI DAN PENYELESAIAN KEKERASAN SEKSUAL DI PERGURUAN TINGGI
}

\author{
Abdul Hamid \\ Universitas Islam Kalimantan Muhammad Arsyad Al-Banjari \\ Jl. Adhyaksa No. 2 Kayu Tangi, Banjarmasin, Kalimantan Selatan. \\ Email: ahamidsh@gmail.com
}

Submitted

: 10 Desember 2021

Revised

: 29 Desember 2021

Accepted

: 31 Desember 2021

Published

Jurnal Al Adl by Universitas Islam Kalimantan Muhammad Arsyad albanjari is licensed under a Creative Commons Attribution 4.0 International License. (CC-BY)

\begin{abstract}
This research aims to analyze the efforts to regulate the anticipation and sexual assault settlement in universities and the legal perspective on the Regulation of the Minister of Education and Culture No. 30 of 2021 on prevention and handling sexual assault in universities. This research applied a normative research methodanalyzing existing laws and regulations according to the case. The results revealed that the efforts to regulate the anticipation and sexual assault settlement in universities were only regarded as a complement and repetition of various existing laws and regulations applied in Indonesia today, with the exception of some acts - considered not including sexual assault acts if there is consent of both parties. The legal perspective on the minister's regulations raises different polemics and arguments in the community. The arguments built in the minister's regulations were an effort to anticipate and settle the existence of crimes, particularly sexual assault for students on campus. However, the existence of the phrase "victim consent" exactly contradicts or does not go with religious values and norms in society as it leads to promiscuity and free sex made by mutual consent, and eventually the female student ( $a$ woman) becomes the aggrieved party.
\end{abstract}

Keywords: Law; Anticipation and Settlement; Sexual assault.

\section{Abstrak}

Penelitian ini bertujuan untuk menganalisis upaya pengaturan antisipasi dan penyelesaian kekerasan seksual di perguruan tinggi dan perspektif hukum terhadap Peraturan Menteri Pendidikan dan Kebudayaan Nomor 30 Tahun 2021 tentang Pencegahan dan Penanganan Kekerasan Seksual Di Lingkungan Perguruan Tinggi. Metode yang digunakan adalah metode penelitian normatif yang menganalisis peraturan perundang-undangan yang ada sesuai dengan masalahnya. Hasil penelitian menemukan upaya pengaturan antisipasi dan penyelesaian kekerasan seksual di perguruan tinggi hanya sebagai pelengkap dan pengulangan dari berbagai peraturan perundang-undangan yang ada dan berlaku di Indonesia sekarang ini, dengan pengecualian beberapa perbuatan dianggap tidak termasuk perbuatan kekerasan seksual apabila ada persetujuan kedua belah pihak. Perspektif hukum terhadap peraturan menteri tersebut, menimbulkan polemik dan argumentasi yang berbeda di masyarakat. Argumentasi yang dibangun dalam peraturan menteri tersebut untuk berupaya melakukan antisipasi dan penyelesaian adanya kejahatan khususnya kekerasan seksual bagi mahasiswi di 
lingkungan kampus. Tetapi adanya frase "persetujuan korban” justeru menabrak atau bertentangan nilai-nilai agama dan norma di masyarakat karena menimbulkan pergaulan dan hubungan seks bebas yang dilakukan dengan dasar suka sama suka, dan pada akhirnya yang dirugikan adalah mahasiswi (perempuan).

Kata Kunci: Hukum; Antisipasi dan Penyelesaian; Kekerasan Seksual.

\section{PENDAHULUAN}

Negara Republik Indonesia dalam Undang-Undang Dasar Negara Republik Indonesia Tahun 1945 telah menempatkan secara tersendiri dan khusus dalam BAB X tentang Warga Negara dan Penduduk, dan BAB XA tentang Hak Asasi Manusia yang berhubungan dengan hak-hak dan kewajiban negara dan warga negara. Seperti hak warga negara bersamaan kedudukannya di dalam hukum dan pemerintahan dan wajib menjunjung hukum dan pemerintahan itu dengan tidak ada kecualinya, ${ }^{1}$ setiap anak warga negara Indonesia berhak atas kelangsungan hidup, tumbuh, dan berkembang serta berhak mendapatkan perlindungan dari kekerasan dan diskriminasi, ${ }^{2}$ dan setiap orang berhak atas pengakuan, jaminan, perlindungan dan kepastian hukum secara adil, dan perlakuan yang sama di hadapan hukum, ${ }^{3}$ berhak atas perlindungan diri pribadi, keluarga, kehormatan, martabat, dan harta benda yang berada di bawah kekuasaannya, berhak atas rasa aman dan perlindungan dari ancaman ketakutan untuk berbuat dan/atau tidak berbuat sesuatu yang merupakan hak asasi manusia, ${ }^{4}$ berhak bebas dari perlakuan diskriminatif atas dasar apapun dan berhak mendapatkan perlindungan terhadap perlakuan diskriminatif, negara atau pemerintah bertanggungjawab atas perlindungan, pemajuan, penegakkan dan pemenuhan hak asasi manusia, dan untuk menegakkan dan melindungi hak asasi manusia sesuai sesuai prinsip negara hukum yang demokratis maka diatur dengan peraturan perundang-undangan, ${ }^{5}$ dan setiap orang wajib menghormati hak asasi manusia orang lain dalam tertib kehidupan masyarakat, bangsa dan negara, dan setiap orang harus tunduk kepada pembatasan yang ditetapkan peraturan perundang-undangan dengan maksud semata-mata untuk menjamin pengakuan dan penghormatan atas hak dan kebebasan orang lain untuk memenuhi tuntutan yang adil sesuai moral, nilai agama, keamanan, ketertiban umum dalam masyarakat demokratis. ${ }^{6}$

Perempuan seringkali mengalami kekerasan, dan kekerasan yang dialami perempuan merupakan gejala sosial yang tidak dapat disembunyikan lagi karena sudah menjadi bagian

\footnotetext{
${ }^{1}$ Pasal 27 Ayat (1) Undang-Undang Dasar Negara Republik Indonesia Tahun 1945.

${ }^{2}$ Pasal 28B Ayat (2) Undang-Undang Dasar Negara Republik Indonesia Tahun 1945.

${ }^{3}$ Pasal 28D Ayat (1) Undang-Undang Dasar Negara Republik Indonesia Tahun 1945.

${ }^{4}$ Pasal 28G Ayat (1) Undang-Undang Dasar Negara Republik Indonesia Tahun 1945.

${ }^{5}$ Pasal 28I Ayat (2), (4), dan (5) Undang-Undang Dasar Negara Republik Indonesia Tahun 1945.

${ }^{6}$ Pasal 28J Ayat (1) dan (2) Undang-Undang Dasar Negara Republik Indonesia Tahun 1945.
} 
tidak terpisahkan dengan kehidupan manusia. kekerasan terhadap perempuan dapat mengakibatkan perusakan emosi, psikologi, seksual, fisik, dan/atau materiil. Kekerasan terhadap perempuan dapat dilakukan secara perorangan atau kelompok. ${ }^{7}$ Tindakan Kekerasan terhadap perempuan dapat terjadi dalam berbagai lingkungan seperti lingkungan rumah tangga, keluarga, masyarakat, ${ }^{8}$ dan juga di lingkungan sekolah, perguruan tinggi, dan tempat bekerja. Bahkan ada kekerasan bagi perempuan dalam rumah tangga, ${ }^{9}$ kekerasan dalam masa pacaran, ${ }^{10}$ kekerasan di ruang publik $^{11}$, dan negara pun sering melakukan kekerasan. ${ }^{12}$ Dampak adanya kekerasan bagi perempuan antara lain mengurangi rasa percaya diri perempuan, mengganggu kemampuan perempuan untuk berpartisipasi dalam kegiatan sosial, menganggu kesehatan, mengurangi otonomi perempuan diberbagai bidang seperti ekonomi, politik dan budaya. $^{13}$

Oleh karena itu, negara wajib memberikan perlindungan terhadap semua warga negara Indonesia tanpa terkecuali termasuk perempuan. Berbagai bentuk kekerasan bagi perempuan yang dianggap lemah dibanding laki-laki, menjadikan perempuan sebagai salah satu obyek atau sasaran kejahatan. Kekerasan bagi perempuan itu beragam mulai dari kekerasan fisik, psikologis, ekonomi, hingga kekerasan seksual. ${ }^{14}$ Hak-hak dan kewajiban dasar warga negara tersebut telah dijamin oleh negara, karena itu maka negara juga mempunyai hak dan kewajiban terhadap semua warga negara tanpa terkecuali untuk tunduk dan patuh dengan peraturan perundang-undangan yang berlaku dengan segala aspek kehidupan bermasyarakat, berbangsa dan bernegara. Salah satu aspek tersebut adalah warga masyarakat di perguruan tinggi. Pelanggaran dan kejahatan juga terjadi di perguruan tinggi di Indonesia, seperti kejahatan kekerasan seksual. Karena itu perlu dilakukan berbagai upaya agar tidak membawa dampak negatif terhadap kualitas penyelenggaraan perguruan tinggi. Dengan dalil untuk mencegah terjadinya kekerasan dan pelecehan seksual terhadap mahasiswa dalam lingkungan kampus. Menteri Pendidikan dan Kebudayaan Nadiem Makarim, mengeluarkan Peraturan

\footnotetext{
${ }^{7}$ Maria Silvya E. Wangga, (2007), "Kekerasan Dalam Rumah Tangga Dan Usaha Merumuskan Familial Yang Demokratis", Jurnal Ilmu Hukum Universitas Islam Syekh Yusuf, Tangerang, 2007, hlm. 1.

${ }^{8}$ Maria Silvya E. Wangga, R. Bondan Agung Kardono, (2012), "Alternatif Penyelesaian Kekerasan Terhadap Perempuan”, Adil: Jurnal hukum, Volume 9 Nomor 2, Tangerang, 2015. hlm. 79.

${ }^{9}$ Umin Kango, (2009), "Bentuk-Bentuk Kekerasan Yang Dialami Perempuan", Jurnal Legalitas, Volume 2 Nomor 1, Februari 2009, hlm. 14.

${ }^{10}$ Umin Kango, Ibid, hlm. 16.

${ }^{11}$ Ibid., hlm. 18.

12 Ibid.

${ }^{13}$ Ruby Hadiarti Johny, (2011), "Tindak Pidana Kekerasan Terhadap Perempuan (Studi Etiologi Kriminal Di Wilayah Hukum Polres Banyumas)", Jurnal Dinamika Hukum, Volume 11 Nomor 2, 2 Mei 2011, hlm. 215.

${ }^{14}$ Kurnia Muhajarah, (2016), "Kekerasan Terhadap Perempuan Dalam Rumah Tangga", Jurnal Sawwa, Volume 11 Nomor 2, April 2016, hlm.130.
} 
Menteri Pendidikan dan Kebudayaan Nomor 30 Tahun 2021 tentang Pencegahan dan Penanganan Kekerasan Seksual Di Lingkungan Perguruan Tinggi. Konon peraturan ini lahir dan didasari banyaknya laporan atau pengaduan tentang adanya pelecehan seksual yang dilakukan oleh dosen, pegawai dan pejabat di perguruan tinggi terhadap mahasiswa. Bahkan Menteri Agama juga mendukung adanya Peraturan Menteri Pendidikan dan Kebudayaan Nomor 30 Tahun 2021 tentang Pencegahan dan Penanganan Kekerasan Seksual Di Lingkungan Perguruan Tinggi tersebut.

Ternyata Peraturan Menteri Pendidikan dan Kebudayaan Nomor 30 Tahun 2021 tentang Pencegahan dan Penanganan Kekerasan Seksual Di Lingkungan Perguruan Tinggi tersebut, menimbulkan reaksi beragam dari berbagai pihak, yaitu ada pihak bersikap pro dan ada juga bersikap kontra, tentu saja dengan argumentasinya masing-masing. Ada pihak yang menilai bertentangan dengan norma-norma yang berlaku dan hidup selama ini di masyarakat. Organisasi kemasyarakatan Islam misalnya, Majelis Ulama Indonesia (MUI) Pusat, menilai mengatakan justru adanya Peraturan Menteri Pendidikan dan Kebudayaan Nomor 30 Tahun 2021 tentang Pencegahan dan Penanganan Kekerasan Seksual Di Lingkungan Perguruan Tinggi tersebut justru menimbulkan kesan pemerintah telah melegalkan seks bebas. Misalnya adanya frase "tanpa persetujuan korban". Telah menimbulkan penolakan terhadap hal tersebut. Sebab apabila dipahami adanya frase "tanpa persetujuan korban" tersebut maka apabila hubungan seksual yang dilakukan dengan adanya persetujuan kedua belah pihak berarti sah-sah saja. Dengan demikian hubungan seksual demikian dianggap legal dan pemerintah membiarkannya. Oleh karena itu, peneliti dalam penelitian ini akan membahas dan menganalis sesuai dengan rumusan masalah yang ada.

\section{RUMUSAN MASALAH}

Berdasarkan latar belakang seperti yang terurai dalam pendahuluan tersebut, maka rumusan masalah dalam penelitian ini adalah:

1. Apa upaya pengaturan antisipasi dan penyelesaian kekerasan seksual di lingkungan perguruan tinggi berdasarkan Peraturan Menteri Pendidikan dan Kebudayaan Nomor 30 Tahun 2021 tentang Pencegahan dan Penanganan Kekerasan Seksual Di Lingkungan Perguruan Tinggi?

2. Bagaimana perspektif hukum terhadap Peraturan Menteri Pendidikan dan Kebudayaan Nomor 30 Tahun 2021 tentang Pencegahan dan Penanganan Kekerasan Seksual Di Lingkungan Perguruan Tinggi? 


\section{METODE PENELITIAN}

Metode penelitian dalam penelitian ini adalah metode penelitian normatif. yaitu penelitian yang yang mengkaji dan menganalisis hukum positif sistematis dan teoritis berhubungan dengan perspektif hukum terhadap dengan adanya Peraturan Menteri Pendidikan dan Kebudayaan Nomor 30 Tahun 2021 tentang Pencegahan dan Penanganan Kekerasan Seksual Di Lingkungan Perguruan Tinggi, khususnya ketentuan-ketentuan hukum yang berlaku dan kedudukannya lebih tinggi. Penelitian hukum normatif mempunyai kharakteristik sebagai penelitian kepustakaan (literature research) yang berbeda dengan metode penelitian empiris (non dokrinal) yang memiliki kharakteristik penelitian lapangan (field study). ${ }^{15}$ Dalam penelitian normatif ini, peneliti berusaha menguraikan secara sistematis, teoritis, ketentuan hukum positif, dan konflik hukum terhadap dengan adanya Peraturan Menteri Pendidikan dan Kebudayaan Nomor 30 Tahun 2021 tentang Pencegahan dan Penanganan Kekerasan Seksual Di Lingkungan Perguruan Tinggi, khususnya yang ketentuan-ketentuan yang diatur dalam Peraturan perundang-undangan yang berlaku dan kedudukannya lebih tinggi.

Pendekatan dalam penelitian ini adalah pendekatan peraturan perundang-undangan (statute approach) yaitu dengan menganalis peraturan perundang-undangan yang ada hubungannya dengan masalah penelitian, dan mencari ratio legis dan dasar ontologism sehingga terbitnya peraturan perundang-undangan tersebut sehingga didapatkan suatu aturan yang relevan untuk memecahkan masalah hukum yang ada, dan pendekatan secara konseptual (conceptual approach), yaitu melakukan pendekatan dengan cara mencari teori, konsep dan dokrin hukum yang ada hubungannya dengan masalah penelitian yang dijadikan pedoman untuk memahami pandangan dalam membangun argomentasi hukum yang sedang diteliti. $^{16}$

Dalam penelitian ini, peneliti menggunakan bahan hukum primer dan bahan hukum sekunder. Bahan hukum primer merupakan bahan hukum yang diambil dan bersumber yang berasal dari berbagai peraturan perundang-undangan yang berlaku dan berhubungan dengan rumusan masalah dalam penelitian, seperti:

1. Undang-Undang Dasar Negara Republik Indonesia Tahun 1945.

2. Undang-Undang Nomor 1 Tahun 1946 tentang Kitab Undang-Undang Hukum Pidana (KUHPidana).

\footnotetext{
${ }^{15}$ Nurhayati, Y., Ifrani, I., Said, M.Y., (2021), "Metodologi Normatif dan Empiris Dalam Perspektif Ilmu Hukum", Jurnal Penegakan Hukum Indonesia, Volume 2 Nomor 1, 1-20, https://doi.org/10.51749/jphi.v2iI.14.

${ }^{16}$ Peter Mahmud Marzuki, (2005), Penelitian Hukum, Surabaya: Kencana, hlm. 93-94.
} 
3. Kitab Undang-Undang Hukum Perdata (KUHPerdata)

4. Undang-Undang Nomor 8 Tahun 1981 tentang Kitab Undang-Undang Hukum Acara Pidana (KUHAP).

5. Undang-Undang Nomor 12 Tahun 1995 tentang Lembaga Pemasyarakat.

6. Undang-Undang Nomor 39 Tahun 1999 tentang Hak Asasi Manusia.

7. Undang-Undang Nomor 35 Tahun 2014 tentang Perubahan Atas Undang-Undang Nomor 23 Tahun 2002 tentang Perlindungan Anak.

8. Undang-Undang Nomor 12 Tahun 1995 tentang Lembaga Permasyarakat.

9. Undang-Undang Nomor 44 Tahun 2008 tentang Pornografi.

10. Peraturan Presiden Republik Indonesia Nomor 25 Tahun 2005 tentang Komisi Nasional Anti Kekerasan Terhadap Perempuan.

11. Peraturan Menteri Pendidikan dan Kebudayaan Nomor 30 Tahun 2021 tentang Pencegahan dan Penanganan Kekerasan Seksual Di Lingkungan Perguruan Tinggi.

Bahan hukum sekunder merupakan bahan hukum yang diambil dan bersumber dari berbagai berbagai jenis buku hukum, jurnal hukum, kamus hukum yang ada berhubungan dengan rumusan masalah dalam penelitian. Penelitian ini bersifat deskriptif analisis, yaitu penelitian yang menggambarkan berbagai peraturan perundang-undangan yang berlaku yang berhubungan dengan teori hukum, konsep hukum, dan dokrin hukum. Dalam penelitian bersifat diskriptif (descriptive reseach) memiliki arti sebagai suatu penelitian yang menggambarkan atau menguraikan suatu keadaan sejelas mungkin berdasarkan kenyataan yang sebenarnya. ${ }^{17}$

\section{PEMBAHASAN}

Upaya pengaturan antisipasi dan penyelesaian kekerasan seksual di lingkungan Perguruan Tinggi berdasarkan Peraturan Menteri Pendidikan dan Kebudayaan Nomor 30 Tahun 2021 tentang Pencegahan dan Penanganan Kekerasan Seksual Di Lingkungan Perguruan Tinggi.

Setelah membaca dan mencermati materi muatan yang terdapat dalam Peraturan Menteri Pendidikan dan Kebudayaan Nomor 30 Tahun 2021 tentang Pencegahan dan Penanganan Kekerasan Seksual Di Lingkungan Perguruan Tinggi, yang ditetapkan Menteri Pendidikan, Kebudayaan, Riset, dan Teknologi Republik Indonesia yaitu mnNadiem Anwar Makarim, pada tanggal 31 Agustus 2021 dan diundangkan pada tanggal 03 September 2021 dalam Berita Negara Republik Indonesia Tahun 2021 Nomor 1000, oleh Direktur Jendral

\footnotetext{
${ }^{17}$ Abdul Hamid, (2019), Rekonstruksi Tata Kelola Hakim Dalam Memeriksa Pelaku Tindak Pidana Anak Berbasis Nilai Keadilan, Disertasi, Program Doktor Ilmu Hukum Fakultas Hukum Universitas Islam Sultan Agung, Semarang: Unissula, hlm. 94.
} 
Peraturan Perundang-Undangan Kementerian Hukum dan Hak Asasi Manusia Republik Indonesia yaitu Benny Riyanto.

Kata antisipasi sinonimnya adalah pencegahan. Dengan demikian upaya pencegahan adalah upaya berupa tindakan, cara, proses yang dilakukan agar seseorang atau kelompok orang tidak melakukan kekerasan seksual di lingkungan perguruan tinggi. ${ }^{18}$ Pencegahan berasal dari kata cegah yang berarti tangkal, mencegah berarti menahan agar sesuatu tidak terjadi, merintangi, mengikhtiarkan agar tidak terjadi. Pencegahan berarti proses, cara, perbuatan mencegah, menegahan, penolakan. ${ }^{19}$ Kata penanganan sinonimnya adalah penyelesaian. Dengan demikian upaya penanganan adalah upaya berupa tindakan, cara, proses untuk menangani kekerasan seksual di lingkungan perguruan tinggi. ${ }^{20}$ Upaya pemeriksaan adalah upaya berupa tindakan, cara, proses yang dilakukan oleh perguruan tinggi untuk menindaklanjuti laporan kekerasan seksual di lingkungan perguruan tinggi. ${ }^{21}$ Pemeriksaan berarti proses, cara, perbuatan memeriksa, hasil (pendapatan) memeriksa, periksaan, penyelidikan, pengusutan (perkara dsb). ${ }^{22}$

Peraturan Menteri Pendidikan dan Kebudayaan Nomor 30 Tahun 2021 tentang Pencegahan dan Penanganan Kekerasan Seksual Di Lingkungan Perguruan Tinggi, bertujuan untuk menjadikan dasar pedoman bagi perguruan tinggi guna menyusun kebijakan dan mengambil tindakan pencegahan dan penanganan kekerasan seksual yang berhubungan dengan pelaksanaan Tridharma di dalam atau di luar kampus, dan untuk menumbuhkan kehidupan kampus yang manusiawi, bermartabat, setara, inklusif, kolaboratif, tanpa kekerasan di antara mahasiswa, pendidik, tenaga kependidikan, warga kampus di perguruan tinggi. ${ }^{23}$ Dengan demikian, terhadap tindakan kekerasan lainnya di luar kejahatan kekerasan seksual yang terjadi di perguruan tinggi, menjadi kewenangan kepolisian dan bukan perguruan tinggi. Sangat kontradiktif dengan kejahatan kekerasan seksual di perguruan tinggi seharusnya juga tetap menjadi kewenangan pihak kepolisian untuk melakukan tindakan hukum sesuai dengan hukum yang berlaku, dimana sanksinya sudah sangat jelas. Seharusnya kejadian yang terjadi

\footnotetext{
${ }^{18}$ Pasal 1 angka 3 Peraturan Menteri Pendidikan dan Kebudayaan Nomor 30 Tahun 2021 tentang Pencegahan dan Penanganan Kekerasan Seksual Di Lingkungan Perguruan Tinggi.

${ }^{19}$ Departemen Pendidikan Nasional, (2005), Kamus Besar Bahasa Indonesia, Edisi Ketiga, Jakarta: Balai Pustaka, hlm. 199.

${ }^{20}$ Pasal 1 angka 4 Peraturan Menteri Pendidikan dan Kebudayaan Nomor 30 Tahun 2021 tentang Pencegahan dan Penanganan Kekerasan Seksual Di Lingkungan Perguruan Tinggi.

${ }^{21}$ Pasal 1 angka 5 Peraturan Menteri Pendidikan dan Kebudayaan Nomor 30 Tahun 2021 tentang Pencegahan dan Penanganan Kekerasan Seksual Di Lingkungan Perguruan Tinggi.

${ }^{22}$ Departemen Pendidikan Nasional, Op.Cit., hlm. 859.

${ }^{23}$ Pasal 2 Peraturan Menteri Pendidikan dan Kebudayaan Nomor 30 Tahun 2021 tentang Pencegahan dan Penanganan Kekerasan Seksual Di Lingkungan Perguruan Tinggi.
} 
di perguruan tinggi yang bertentangan dengan hukum diserahkan pada pihak kepolisian, sedang hal-hal yang bertentangan dengan peraturan perguruan tinggi diserahkan kepada dewan kode etik yang sanksinya juga sudah jelas. Apalagi bagi perguruan tinggi negeri yang tunduk kepada Undang-Undang Nomor 5 Tahun 2014 tentang Aparatur Sipil Negara, dan Undang-Undang Nomor 20 Tahun 2003 tentang Sistem Pendidikan Nasional, UndangUndang Nomor 12 Tahun 2012 tentang Pendidikan Tinggi, dan peraturan perundangundangan lainnya. Sudah menjadi tujuan hukum untuk memberikan perlindungan bagi seluruh warga negara dan sekaligus menegakkan hukum apabila dilanggar mendapatkan hukuman pidana yang sesuai dengan kejahatan atau pelanggarannya.

Pengertian kekerasan seksual adalah setiap perbuatan merendahkan, menghina, melecehkan, dan/atau menyerang tubuh, dan/atau fungsi reproduksi seseorang, karena ketimpangan relasi kuasa dan/atau gender, yang berakibat atau dapat berakibat penderitaan psikis dan/atau fisik termasuk yang menganggu kesehatan reproduksi seseorang dan hilang kesempatan melaksanakan pendidikan tinggi dengan aman dan optimal. ${ }^{24}$

Kekerasan seringkali terjadi di kehidupan sehari-hari baik di lingkungan keluarga, masyarakat. Kekerasan secara umum dialami oleh orang-orang yang tidak berdaya, khususnya terhadap perempuan. Kekerasan terhadap perempuan menjadi momok yang sangat menakutkan tidak saja bagi dirinya sendiri tetapi juga keluarga dan masyarakat. Kekerasan seksual misalnya, terjadi dikarenakan tata nilai umum yang memposisikan perempuan sebagai makhluk lemah dan dipandang lebih rendah dibandingkan laki-laki. Sebagian masyarakat masih menilai kaum perempuan sebagai kaum marginal, dikuasai, dieksploitasi, dan menjadi budak oleh laki-laki. ${ }^{25}$ Termasuk pelecehan seksual secara verbal berupa catcalling karena berpotensi sebagai suatu tindak pidana yang terjadi di ruang lingkup publik dengan unsurunsur tindak pidana yang mengakibatkan terganggunya mental, psikologis, dan kejiwaan. ${ }^{26}$ Kejahatan pelecehan seksual pada dasarnya merupakan suatu kenyataan yang ada dalam kehidupan masyarakat dewasa ini. Kekerasan terhadap perempuan adalah suatu tindakan yang tidak manusiawi. Perempuan berhak menikmati dan memperoleh perlindungan hak asasi

\footnotetext{
${ }^{24}$ Pasal 1 angka 1 Peraturan Menteri Pendidikan dan Kebudayaan Nomor 30 Tahun 2021 tentang Pencegahan dan Penanganan Kekerasan Seksual Di Lingkungan Perguruan Tinggi.

${ }^{25}$ Utami Zahirah Noviani P, Rifdah Afifah K, Cecep Sahadi Humaeni, (2018), "Mengatasi dan Mencegah Tindak Kekerasan Seksual Pada Perempuan Dengan Pelatihan Asertif', Jurnal Penelitian dan PPM, Volume 5 , Nomor 1, April 2018, hlm. 49.

${ }^{26}$ Yuni Kartika, Andi Najemi, (2020), "Kebijakan Hukum Perbuatan Pelecehan Seksual (Catcaliling) Dalam Persepektif Hukum Pidana”, Jurnal PAMPAS Journal of Criminal Law,, Volume 1, Nomor 2, Juni 2020, hlm. 1 .
} 
manusia dan kebebasaan di segala bidang. ${ }^{27}$ Kekerasan terhadap perempuan dan juga anak bukan saja masalah individual, masyarakat, nasional saja tetapi sudah menjadi masalah global dan transnasional, yang berakibat timbul berbagai istilah seperti violence against women, gender based violence, gender violence, domestic violence yang korbannya adalah perempuan. ${ }^{28}$ Karena masalah kekerasan seksual sudah dianggap sebagai sebuah masalah hukum yang harus mendapatkan perhatian dan pengananan secara khusus itulah pemerintah melalui kementeriannya mengeluarkan Peraturan Menteri Pendidikan dan Kebudayaan Nomor 30 Tahun 2021 tentang Pencegahan dan Penanganan Kekerasan Seksual Di Lingkungan Perguruan Tinggi. Sebenarnya sudah banyak peraturan perundang-undangan di Indonesia, yang mengatur dan memberikan perlindungan khusus terhadap perempuan dan anak, seperti dalam kitab Undang-Undang Hukum Pidana (KUHPidana) yang bersifat umum, dan peraturan perundang-undangan lainnya yang bersifat khusus seperti Undang-Undang Nomor 39 Tahun 1999 tentang Hak Asasi Manusia, Undang-Undang Nomor 35 Tahun 2014 tentang Perubahan Atas Undang-Undang Nomr 23 Tahun 2002 tentang Perlindungan Anak, Undang-Undang Nomor 44 Tahun 2008 tentang Pornografi, Undang-Undang Nomor 11Tahun 2008 tentang Informasi dan Transaksi Elektronik, Peraturan Presiden Republik Indonesia Nomor 25 Tahun 2005 tentang Komisi Nasional Anti Kekerasan Terhadap Perempuan, dan masih banyak lagi peraturan perundang-undangan lainnya.

Pengaturan antisipasi dan penyelesaian kejahatan kekerasan seksual di perguruan tinggi sebagaimana diatur dalam Peraturan Menteri Pendidikan dan Kebudayaan Nomor 30 Tahun 2021 tentang Pencegahan dan Penanganan Kekerasan Seksual Di Lingkungan Perguruan Tinggi tersebut, dianggap sebagai dasar hukum bagi perguruan tinggi sebagaimana ketentuan Pasal 2 Ayat (1) dan (2). Maka sebenarnya sudah ada Peraturan Presiden Republik Indonesia Nomor 25 Tahun 2005 tentang Komisi Nasional Anti Kekerasan Terhadap Perempuan, yang dibentuk dalam rangka antisipasi atau pencegahan dan penanggulangan atau penyelesaian masalah kekerasan terhadap perempuan serta penghapusan segala bentuk kekerasan yang dilakukan terhadap perempuan, yaitu Komisi Nasional Anti Kekerasan Terhadap Perempuan. Tujuan dibentuknya adalah untuk menciptakan keadaan kondusif bagi penghapusan semua bentuk kejahatan kekerasan bagi perempuan dan penegakkan atas hak-

\footnotetext{
${ }^{27}$ Venny Melisa Marbun, Randa Kristianta Purba, Rahmayanti, (2020), “Analisis Yuridis Terhadap Tindak Pidana Pelecehan Seksual Kepada Anak di Bawah Umur ", Adil Jurnal Hukum,, Volume 11, Nomor 1, 2020, hlm. 134.

${ }^{28}$ Jhon D. Pasalbessy, (2010), "Dampak Tindak Kekerasan Terhadap Perempuan dan Anak Serta Solusinya", Jurnal Sasi, Volume 16, Nomor 3, Juli-September 2010, hlm. 8.
} 
hak asasi manusia perempuan di Indonesia, dan meningkatkan agar upaya antisiapasi dan penyelesaian semua bentuk kejahatan kekerasan bagi perempuan dan perlindungan hak-hak asasi manusia perempuan. ${ }^{29}$ Secara hirarki peraturan peraturan perundang-undangan di Indonesia, kedudukan Peraturan Presiden Republik Indonesia Nomor 25 Tahun 2005 tentang Komisi Nasional Anti Kekerasan Terhadap Perempuan lebih tinggi daripada Peraturan Menteri Pendidikan dan Kebudayaan Nomor 30 Tahun 2021 tersebut. Walaupun antara keduanya tidak saling bertentangan tetapi telah terjadi tumpang tindih kepentingan yang sama-sama mempunyai tujuan dan maksud yang sama. Di samping itu, peran dari Komisi Nasional Anti Kekerasan Bagi Perempuan, bersifat independen telah dikebiri dengan satuan tugas yang ada di perguruan tinggi. Dalam hal ini, keduanya bekerja sendiri-diri, berbeda, terpisah, tanpa kerjasama serta koordinasi.

Peraturan Menteri Pendidikan dan Kebudayaan Nomor 30 Tahun 2021 tentang Pencegahan dan Penanganan Kekerasan Seksual Di Lingkungan Perguruan Tinggi tersebut, ada beberapa materi atau ketentuan yang menjadi polemik dan perdebatan, yaitu dalam ketentuan Pasal 5 Ayat (2) yang menyatakan, kekerasan seksual sebagaimana ketentuan Ayat (1), ${ }^{30}$ yaitu meliputi:

1. Pada huruf $b$, yaitu memperlihatkan alat kelaminnya dengan sengaja tanpa persetujuan korban. Berarti jika ada persetujuan korban bukan termasuk kekerasan sebagaimana ketentuan Pasal 5 Ayat (1).

2. Pada huruf $\mathrm{f}$ yaitu, mengambil, merekam, dan/atau mengedarkan foto dan/atau rekaman audio dan/atau visual korban yang bernuasa seksual tanpa persetujuan korban. Berarti jika ada persetujuan korban bukan termasuk kekerasan sebagaimana ketentuan Pasal 5 Ayat (1).

3. Pada huruf g, yaitu mengunggah foto tubuh dan/atau informasi pribadi korban yang bernuansa seksual tanpa persetujuan korban. Berarti jika ada persetujuan korban bukan termasuk kekerasan sebagaimana ketentuan Pasal 5 Ayat (1).

4. Pada huruf h, yaitu menyebarkan informasi terkait tubuh dan/atau pribadi korban yang bernuansa seksual tanpa persetujuan korban. Berarti jika ada persetujuan korban bukan termasuk kekerasan sebagaimana ketentuan Pasal 5 Ayat (1).

5. Pada huruf 1, yaitu menyentuh, mengusap, meraba, memegang, memeluk, mencium dan/atau menggosokkan bagian tubuhnya pada tubuh korban tanpa persetujuan korban. Berarti jika ada persetujuan korban bukan termasuk kekerasan sebagaimana ketentuan Pasal 5 Ayat (1).

\footnotetext{
${ }^{29}$ Pasal 2 Peraturan Presiden Republik Indonesia Nomor 25 Tahun 2005 tentang Komisi Nasional Anti Kekerasan Terhadap Perempuan.

${ }^{30}$ Pasal 5 Ayat (1) Peraturan Menteri Pendidikan dan Kebudayaan Nomor 30 Tahun 2021 tentang Pencegahan dan Penanganan Kekerasan Seksual, menyatakan kekerasan seksual mencakup tindakan yang dilakukan secara verbal, nonfisik, fisik, dan/atau melalui teknologi informasi dan komunikasi.
} 
6. Pada huruf $m$, yaitu membuka pakaian korban tanpa persetujuan korban. Berarti jika ada persetujuan korban bukan termasuk kekerasan sebagaimana ketentuan Pasal 5 Ayat (1).

Persetujuan sebagaimana tindakan tersebut, dianggap tidak sah apabila korban dalam keadaan tertentu, yaitu: korban belum berusia dewasa sesuai dengan peraturan perundangundangan, korban dalam keadaan diancam, dipaksa, dan/atau menyalahgunakan kedudukannya, korban dalam pengaruh obat-obatan, alkohol, dan/atau narkoba, korban dalam keadaan sakit, pingsan, dan/atau tertidur, korban memiliki fisik dan/atau psikologis yang rentan, korban mengalami kelumpuhan sementara, korban mengalami kondisi tergoncang. ${ }^{31}$

Menurut hukum positif yang berlaku di Indonesia, masalah tolak ukur usia seseorang dikatakan telah dewasa beraneka macam dan tidak ada kesepakatan antara satu dengan yang lainnya dan masing-masing tergantung dengan peraturan perundang-undangan yang mengaturnya, untuk menentukan seseorang dianggap telah dewasa menurut hukum apabila seorang itu sudah berusia 16 tahun $^{32}$, apabila seorang itu sudah berusia 17 tahun $^{33}$, sudah berusia 18 tahun, ${ }^{34}$ sudah berusia 21 tahun dan/atau kawin ${ }^{35}$. Di lingkungan perguruan tinggi secara umum yang beraktifitas adalah orang dewasa dan mungkin ada mahasiswa yang usianya di bawah 17 tahun. Dengan demikian, apabila terjadi kejahatan dan pelanggaran hukum maka terhadap pelaku diberlakukan ketentuan hukum pidana sebagaimana diatur dalam Kitab Undang-Undang Hukum Pidana (KUHP) dan peraturan perundang-undangan lainnya. Ditinjau dari maksud dan tujuan diadakannya Peraturan Menteri Pendidikan dan Kebudayaan Nomor 30 Tahun 2021 tersebut, ada yang salah. Tetapi yang menjadi masalah adalah adanya beberapa ketentuan ketentuan dalam Pasal 5 Ayat (2) yang dirasa telah melukai perasaan keadilan, norma dan nilai agama serta hukum. Dalam Peraturan Menteri Pendidikan dan Kebudayaan Nomor 30 Tahun 2021, sangat jelas membahayakan dan berpeluang dapat dan akan merusak tatanan hukum dan aqidah bagi umat Islam khususnya di lingkungan

\footnotetext{
${ }^{31}$ Pasal 5 Ayat (3) Peraturan Menteri Pendidikan dan Kebudayaan Nomor 30 Tahun 2021 tentang Pencegahan dan Penanganan Kekerasan Seksual, menyatakan kekerasan seksual mencakup tindakan yang dilakukan secara verbal, nonfisik, fisik, dan/atau melalui teknologi informasi dan komunikasi.

${ }^{32}$ Pasal 45 dan Pasal 72 Undang-Undang Nomor 1 Tahun 1946 tentang Kitab Undang-Undang Hukum Pidana (KUHPidana).

${ }^{33}$ Pasal 283 Undang-Undang Nomor 1 Tahun 1946 tentang Kitab Undang-Undang Hukum Pidana (KUHPidana), Pasal 153 Ayat (1) Undang-Undang Nomor 8 Tahun 1981 tentang kitab Undang-Undang Hukum Acara Pidana (KUHAP).

${ }^{34}$ Pasal 1 angka 1 Undang-Undang Nomor 35 Tahun 2014 tentang Perubahan Atas Undang-Undang Nomor 23 Tahun 2002 tentang Perlindungan Anak, Pasal 1 sub 5 Undang-Undang Nomor 39 Tahun 1999 tentang Hak Asasi Manusia, Pasal 1 Ayat (2) Undang-Undang Nomor 12 Tahun 1995 tentang Lembaga Pemasyarakat.

${ }^{35}$ Pasal 330 Ayat (1), Pasal 419 Kitab Undang-Undang Hukum Perdata, Peraturan Pemerintah Nomor 2 Tahun 1988 tentang Usaha Kesejahteraan Anak Bagi Anak yang Mempunyai Masalah.
} 
kampus secara khusus dan masyarakat secara umum. Karena berpeluang menghalalkan seks secara terbuka dan bebas melakukan hubungan seksual secara menyimpang di masyarakat Indonesia. Alasannya sebagai berikut:

1. Frase "tanpa persetujuan" dalam ketentuan Peraturan Menteri Pendidikan dan Kebudayaan Nomor 30 Tahun 2021 tersebut ditempatkan sebagai unsur penentu suatu tindakan atau perbuatan dianggap sebagai perbuatan kekerasan seksual atau pelecehan seksual. Hal ini sebagaimana ketentuan Pasal 5 Ayat (2), angka 1 "menyentuh, mengusap, meraba, memegang, memeluk, mencium dan/atau menggosokan bagian tubuhnya pada tubuh korban tanpa persetujuan korban”. Sangat jelas dan tegas dalam ketentuan Pasal tersebut, persetujuan menjadi sangat berperan dan mempengaruhi serta penentu suatu tindakan, perbuatan atau hubungan seksual dipandang sebagai kejahatan seksual. Dimana sepanjang tindakan ataau perbuatan seksual yang dilakukan terjadi karena adanya kesepakatan atau keinginan kedua belah pihak maka tindakan atau perbuatan seksual tersebut merupakan sesuatu yang legal dan dibenarkan secara hukum. Itu artinya merupakan salah satu hak warga negara, dan negara tidak ada kewenangan untuk menindaknya, dan penindaknya berarti pelanggaran terhadap hak warga negara dan melanggar hukum.

Merujuk terhadap ketentuan Pasal 5 Peraturan Menteri Pendidikan dan Kebudayaan Nomor 30 Tahun 2021. Maka bukan hanya sekedar tindakan atau perbuatan seksual di luar nikah saja, tindakan menggugurkan kandungan (aborsi) juga diperbolehkan dilakukan atas persetujuan masing-masing pihak. Sangat berbahaya apabila adanya kesepakatan dan keinginan kedua belah pihak menghalalkan atau melegalkan berbuatan yang bernuasa seksual dan merendahkan perempuan khususnya mahasiswi serta melanggar nilai-nilai agama dan norma yang berlaku di masyarakat Indonesia. Cara berpikir liberal telah merasuki pengambil kebijakan di negara Indonesia, khususnya di dunia pendidikan seperti yang terjadi sekarang ini. Hal tersebut ternyata merupakan pola berpikir liberal yang diambil dari CEDAW (Convention on the Elimunation of All Forms of Discrimination Againt Women) yaitu perjanjian hak asasi Internasional yang khusus mengatur hak-hak perempuan. Dasar dari pikiran tersebut adalah perbuatan seks di luar nikah adalah hak warga negara. Negara dan agama apapun tidak diperbolehkan ikut terlibat dan campur tangan didalamnya.

2. Adanya kekhawatiran bahwa Peraturan Menteri Pendidikan dan Kebudayaan Nomor 30 Tahun 2021 tersebut, berpotensi memberikan perlindungan adanya prilaku penyimpangan 
seksual seperti kaum Lesbian, Gay, Biseksual, dan Transgender (LGBT). Seperti tercantum dalam ketentuan Pasal 5 Ayat (2) bagian a menyatakan kekerasan seksual meliputi: "menyampaikan ujaran yang mendiskriminasi atau melecehkan tampilan fisik, kondisi tubuh, dan/atau identitas gender korban". Kata "identitas gender" tersebut bukan sekedar berjenis kelamin laki-laki atau jenis kelamin perempuan, tetapi juga termasuk dalam pengertian gay atau lesbian. Dengan demikian, di lingkungan kampus (pendidikan) tidak boleh ada yang mengkritisi apalagi melarang ativitas kaum LGBT, karena termasuk tindakan atau perbuatan ujaran kebencian dan diskriminatif yang dapat digolongkan sebagai kekerasan seksual.

3. Adanya satuan tugas sebagaimana Peraturan Menteri Pendidikan dan Kebudayaan Nomor 30 Tahun 2021 tersebut, sebagai unit penyelesaian kekerasan seksual di Kampus berpotensi ditempati dan diisi oleh orang yang berpaham feminis dan liberal sebagai penafsir tunggal penyelesaian kekerasan seksual di Kampus. Hal ini sebagaimana ketentuan Pasal 24 Ayat (4) Peraturan Menteri Pendidikan dan Kebudayaan Nomor 30 Tahun 2021 tersebut, menyatakan "anggota panitia seleksi sebagaimana dimaksud Ayat (1) harus memenuhi syarat yaitu: sudah mendampingi korban kekerasan seksual, sudah melakukan kajian tentang kekerasan seksual, gender, dan/atau disabilitas, sudah mengikuti organisasi di dalam atau di luar kampus yang fokusnya di isu kekerasan seksual, gender, dan/atau disabilitas, dan belum pernah terbukti melakukan kekerasan termasuk kekerasan seksual. Ketentuan tersebut, berpotensi tidak memberikan kesempatan dan peluang kepada aktivis atau kelompok-kelompok studi Islam yang secara pasti mempunyai persepektif yang berbeda secara diametral dengan kalangan feminisme dan liberalis untuk berpertisipasi dalam mengantisipasi dan penyelesaian kejahatan kekerasan seksual di perguruan tinggi.

Bentuk kejahatan kekerasan paling sering terjadi pada perempuan antara lain, kekerasan tubuh (fisik) dan kekerasan non-fisik. Kedua bentuk kekerasan tersebut saling berhubungan dan mengkukuhkan kekuasaan pelaku untuk melakukan kekerasan. Kekerasan fisik dapat berupa semua perbuatan yang menimbulkan penderitan secara fisik, seperti menampar, memukul, mengikat, membenturkan, mendorong dan sebagainya. Kekerasan nonfisik dapat berupa memaki, berkata jorok, menyiul, menatap, atau melontarkan lelucon yang berbau seks dan berkonotasi merendahkan perempuan. ${ }^{36}$ Kasus kekerasan terhadap perempuan dapat juga dilakukan oleh media elektronik dengan menyebarkan pemberitaan

\footnotetext{
${ }^{36}$ Umin Kango, Op.Cit., hlm. 14.
} 
secara vulgar tanpa sensor, yang justru sangat menyudutkan korban dan pelaku sekaligus. Khusus terhadap korban mengalami dua peristiwa yang hamper bersamaan, yaitu telah mengalami kejahatan kekerasan oleh pelaku, dan juga mengalami perasaan disudutkan dan di bully secara tidak berimbang oleh media massa. Pandangan memojokkan media massa sebagai akibat terjadinya kejahatan kekerasan bagi perempuan yang dialami korban tidak saja dari kalangan biasa tetapi juga dari kalangan terpelajar dan berpendidikan tinggi, dengan melontarkan kata-kata misalnya dilecehkan dan diperlakukan dengan tidak senonoh karena perempuannya yang kegenitan atau kegatalan dan sebagainya. ${ }^{37}$

\section{Perspektif hukum terhadap Peraturan Menteri Pendidikan dan Kebudayaan Nomor 30} Tahun 2021 tentang Pencegahan dan Penanganan Kekerasan Seksual Di Lingkungan Perguruan Tinggi.

Universitas Indonesia dengan Aliansi Badan Eksekutif Mahasiswa (BEM) seperti: Aliansi Badan Eksekutif Mahasiswa (BEM) Universitas Indonesia terdiri dari BEM FH UI, BEM UI, BEM IKM UI, BEM IM FKM UI, FIK UI, FPsi UI, FT UI, FF UI, FKG UI,VOKASI UI, FMIPA UI, FASILKOM UI, FIA UI, FEP UI, FISIP UI, dan FIB HopeHelps UI mengatasnamakan Aliasi kekerasan seksual dalam kampus Universitas Indonesia (UI) mendorong agar Peraturan Menteri Pendidikan dan Kebudayaan Nomor 30 Tahun 2021 tersebut segera dilaksanakan. Menurut kelompok ini penerbitan Peraturan Menteri Pendidikan dan Kebudayaan Nomor 30 Tahun 2021 tersebut sejatinya merupakan langkah revolusiner atau maju dari pemerintah dengan maraknya kasus kejahatan kekerasan seksual di perguruan tinggi, dan dijadilan dasar hukum secara komprehensif guna mengatur, mengantisipasi dan penyelesaikan kejahatan kekerasan seksual di perguruan tinggi. Lebih lanjut Aliansi BEM UI juga memberikan penjelasan alasan dukungannya dengan mengementari konsep frase consent atau persetujuan yang memiliki beberapa sifat antara lain: persetujuan dimaksud diberikan dalam keadaan sadar tanpa adan pengaruh dan tekanan dari mana pun (freely given).

1. Persetujuan dapat ditarik kembali (reversible).

2. Persetujuan diberikan saat sudah terinformasikan secara benar dan lengkap (informed).

3. Persetujuan diberikan secara antusias (enthusiastic).

37 Rissa Indrasty, Darajat Wibawa, Rojudin, (2018), "Gender Dalam Kasus Kekerasan Terhadap Perempuan Di Media Online”, Jurnal Ilmu Jurnalistik, Volume 3 Nomor 1, Maret 2018, hlm. 93. 
4. Persetujuan diberikan secara specific terhadap suatu tindakan, artinya seseorang yang setuju melakukan sesuatu hal bukan berarti setuju melakukan hal lainnya yang terkait dengan hal yang telah disetujui sebelumnya (specific). ${ }^{38}$

Apabila salah satu sifat dari persetujuan tersebut tidak ada dalam suatu hubungan seksual, maka perbuatan tersebut dapat digolongkan dalam perbuatan kekerasan seksual. Karena itu, Peraturan Menteri Pendidikan dan Kebudayaan Nomor 30 Tahun 2021 tersebut, tidak bertentangan dengan nilai agama dan bahkan seiring dengan nilai agama yaitu menolak kekerasan seksual kepada siapapun. Berdasarkan hal tersebut, peneliti tidak sependapat apabila alasan dukungan terhadap Peraturan Menteri Pendidikan dan Kebudayaan Nomor 30 Tahun 2021 tersebut, karena seandainya semua konsep kesepakatan tersebut terpenuhi maka perbuatan seksualnya menjadi "kelembutan seksual" bukan "kekerasan seksual". Hubungan seksual dengan kelembutan seksual atau kekerasan seksual tidak dibenarkan dalam ajaran agama Islam. Hubungan seksual yang dibenarkan hanya dalam kontek adanya perkawinan yang sah berdasarkan syariah agama Islam itu sendiri, yaitu telah memenuhi rukun dan syarat perkawinan. Konsep hubungan seksual adanya persetujuan antara kedua pelaku dan dilakukan di luar nikah yang dilakukan oleh mahasiswa, pegawai dan dosen di perguruan tinggi sangat berpotensi terjadi dan justru menjadi payung hukum bagi pelakunya untuk berbuat secara bebas dan terbuka. Padahal agama Islam misalnya, sangat jelas dan tegas melarang dan mengharamkan hubungan seksual apapun alasannya kecuali dengan dasar adanya perkawinan. Dikhawatirkan banyak anak yang terlahir dari hubungan seksual dengan persetujuan di luar perkawinan tersebut. Padahal dalam hukum positif yang ada di Indonesia, sudah banyak ketentuan yang mengatur dan mengancam pelaku yang berhubungan seksual di luar nikah. Dengan demikian, apa yang diatur dalam Peraturan Menteri Pendidikan dan Kebudayaan Nomor 30 Tahun 2021 tentang Pencegahan dan Penanganan Kekerasan Seksual Di Lingkungan Perguruan Tinggi tersebut, sebenarnya sudah diatur dalam peraturan perundang-undangan yang lebih tinggi, dan daya berlakunya pun untuk seluruh rakyat Indonesia.

Pandangan Agama Islam terhadap kejahatan seksual terhadap Peraturan Menteri Pendidikan dan Kebudayaan Nomor 30 Tahun 2021 tentang Pencegahan dan Penanganan Kekerasan Seksual Di Lingkungan Perguruan Tinggi tersebut, sudah sangat jelas bertentangan dengan ajaran agama Islam dan sangat membahayakan umat Islam. Dimana WITA).

${ }^{38}$ Tim Detik News, detikcom, https://newsdetik.com (diakses pada 11 November 2021 pukul 11.03 
peraturan tersebut, sangat membuka peluang dan melegalkan hubungan seks bebas tanpa ikatan perkawinan di lingkungan kampus. Penilaian bahwa pihak yang menentang adanya Peraturan Menteri Pendidikan dan Kebudayaan Nomor 30 Tahun 2021 tentang Pencegahan dan Penanganan Kekerasan Seksual Di Lingkungan Perguruan Tinggi tersebut, tidak mendukung pencegahan adanya tindakan, perbuatan dan hubungan seksual adalah tudingan yang bersifat fitnah dan keji serta tidak masuk akal. Kenapa? karena agama Islam adalah satusatunya agama yang melarang bentuk penindasan dan kekerasan bagi makhluk hidup, termasuk melakukan hubungan seksual di luar perkawinan. Dalam Kitab Al-Quran dalam Surah An-Nur (24:33) "janganlah kalian memaksa budak-budak wanita kalian untuk melakukan pelacuran, sedangkan mereka sendiri menginginkan kesucian, karena kalian hendak mencari keuntungan duniawi”. Menurut Ibnu Katsir, pada masa jahiliyah, apabila seseorang memiliki budak perempuan, dan melepaskan perempuan itu untuk melacurkan diri (berzina) dan menetapkan tarif atas dirinya di setiap waktu. Sejak Agama Islam datang, Allah Subhanahu wa ta'ala. Melarang orang-orang berbuat hal tersebut. orang jahiliyyah yang melakukan praktik tersebut misalnya Abdullah Bin Ubay bin Salul, yang memaksa budak perempuann yang dimilikinya untuk melacurkan diri (zina). Agama Islam menentukan ukuran seseorang melakukan perbuatan, tindakan dan hubungan seksual adalah hukum syari'ah itu sendiri. Bukan persetujuan manusia atau hak asasi manusia seperti yang diajarkan dalam pemikiran feminis dan liberal. Pemikiran kaum feminis dan liberal adanya persetujuan kedua belah pihak, karena tidak boleh ada pihak yang boleh mengurus urusan pribadi orang lain, termasuk negara. Orang bebas berbuat apapun termasuk berhubungan seksual dengan binatang dan bahkan mayat.

Penentang Peraturan Menteri Pendidikan dan Kebudayaan Nomor 30 Tahun 2021 tersebut, beranggapan apabila ketentuan ini dilaksanakan tujuan untuk mencegah kekerasan seksual tidak akan terwujud. Malah sebaliknya justru membuat pergaulan bebas semakin subur dan terang-terangan di lingkungan kampus. Bayangan pergaulan mahasiswa di kampus yang menjalin hubungan kekasih (pacaran) terang-terangan dan terbuka serta setiap saat akan terlihat bergandengan tangan, berpelukan, dan berciuman baik yang dilakukan beda jenis kelamin dan sesama kelamin. Alasannya adalah mereka bebas melakukan hal tersebut karena dilakukan secara suka rela dan tidak dipaksa atau memaksa satu sama lain. Pihak kampus tidak bisa berbuat apa-apa jika sudah demikian, salah satu menyebabnya adalah adanya Peraturan Menteri Pendidikan dan Kebudayaan Nomor 30 Tahun 2021, yang telah memberikan perlindungan secara hukum. Perbuatan demikian inilah yang ditakuti dan 
dikhawatirkan. Coba saja perhatikan kehidupan anak kampus dan orang-orang di lingkungan kampus sekarang ini.

Agama Islam tidak pernah memberikan toleransi terhadap pelanggaran atau kejahatan jenis apapun, termasuk kejahatan seksual. Seorang laki-laki yang berhubungan seksual di luar nikah atau memperkosa akan dijatuhi sanksi menurut hukum syari'ah, yaitu:

a. Apabila laki-laki tersebut tidak menikah (ghayr muhshan), hukumannya dihukum cambuk 100 (seratus) kali.

b. Apabila laki-laki tersebut sudah menikah (muhshan, hukumannya akan dirajam hingga mati.

Sebagaimana Al-Quran Surat An Nur (24) Ayat 2 yang artinya "pezina wanita dan penzina laki-laki yang berzina, cambuklah keduanya masing-masing seratus kali cambukan”. Sedangkan terhadap korban perkosaan dibebaskan dari hukuman. Sabda Nabi Muhammad Shalallaahu Alaihi Wassalaam, yang artinya "Allah Subhanahu wa ta'ala sesungguhnya memaafkan umatku karena tidak sengaja berbuat salah, lupa, dan dipaksa (HR. Ibnu Majah dan Al Baihaqi). Perbuatan seksual lainnya semisal meraba, menyentuh, merayu, ujaran katakata kotor juga mendapatkan hukuman secara syari'ah yang akan dijatuhkan oleh hakim (qadhi) di pengadilan. Menurut Syaikh Abdurrahman Al Maliki dalam kitabnya Nizham Al Uqubat Fi Al Islam menyebutkan, orang yang berupaya berbuat zina dengan perempuan tetapi tidak sampai melakukannya, akan dijatuhi hukuman 3 (tiga) tahun penjara, ditambah hukuman cambuk dan pengasingan. Hukumam tersebut, dan ditambah hukumannya apabila korbannya adalah orang yang berada dalam kekuasaannya seperti pembantu atau pegawainya (Syaikh Abdurrahman Al Maliki, Nizham Al Uqubat Fi Al Islam; 93).

Penyimpangan seksual yang dilakukan kalangan LGBT dengan perbuatan homoseksual (gay dan lesbian) merupakan termasuk perbuatan dosa dan mendapatkan ancaman hukuman yang berat. Nabi Muhammad Shalallaahu Alaihi Wassalaam sebagaimana hadist diriwayatkan oleh Ahmad, bersabda yang artinya "barangsiapa yang menjumpai orang yang melakukan perbuatan homo seperti kelakuan kaum Luth, bunuhlah pelaku dan obyeknya”. Agama Islam bahkan menutup celah sekecil apapun untuk mencegah agar tidak ada kejahatan seksual, yaitu dengan cara memerintahkan bagi kaum muslimah untuk menutup auratnya dengan pakaian muslim, menjaga pandangan, dan melarang berkhalwat dengan alasan apapun, tidak dibenarkan laki-laki dengan perempuan berduaan di ruangan tertutup dan sepi meskipun dengan alasan bimbingan skripsi dan lainnya. 
Nabi Muhammad Shalallaahu Alaihi Wassalaam sebagaimana hadist yang diriwayatkan Al Bukhari, bersabda "Barangsiapa beriman Allah dan hari kiamat hendaknya tidak berkhalwat dengan perempuan yang bukan muhrimnya karena pihak ketiganya adalah syetan". Dan "barangsiapa yang beriman kepada Allah dan hari akhir maka janganlah ia berkhalwat dengan seorang perempuan tanpa ada mahram perempuan tersebut, karena orang ketiganya syaitan yang berada di antara keduanya" (HR. Ahmad dari Hadist Jabir 3/339). Khalwat dalam Bahasa Arab berarti bersendirian, kosong, bersih, sesuatu yang lepas. Khalwat adalah berkumpulnya dua orang berlainan jenis secara menyendiri (al ijtima' bayna itsnayni ala infirad) dengan tidak ditemani orang lain selain keduanya di tempat khusus, dan perlu izin keduanya jika ada yang masuk, seperti di rumah atau tempat sunyi dan jauh dari keramaian manusia (An Nidhom Al Ijtimai, An Nabhani: 97). Khalwat dalam pengertian negatif adalah perbuatan berdua-duan di tempat sunyi dan terhambat dari pandangan orang lain antara dua orang yang berlainan jenis dan tidak mahramnya. Khalwat dalam pengertian positif juga dapat diartikan sebagai berbuatan menjauhkan diri dari perhatian orang lain dan menyendiri untuk lebih mendekatkan diri kepada Allah Subhanahu wa ta'ala.

Peraturan Menteri Pendidikan dan Kebudayaan Nomor 30 Tahun 2021 tersebut, telah menjadikan indikator bahwa dalam dunia pendidikan di Indonesia telah mulai dirasuki oleh paham feminisme dan liberalisme. Di mana Peraturan Menteri Pendidikan dan Kebudayaan Nomor 30 Tahun 2021 tersebut, tidak didasari dan bersendikan agama Islam. Budaya dunia barat sedikit demi sedikit dimasukan dan disisipkan ke berbagai aspek kehidupan masyarakat termasuk dalam dunia pendidikan di kampus oleh penguasa yang secara sengaja atau tidak sengaja telah terpapar paham feminisme dan liberalisme.

Kejahatan kesopanan dalam hukum positif di Indonesia, sebagaimana diatur secara tegas dalam Kitab Undang-Undang Hukum Pidana (KUHP) sebagaimana ketentuan UndangUndang Nomor 1 Tahun 1946 tentang Peraturan Hukum Pidana. BAB XIV tentang Kejahatan Kesopanan, Buku II KUHP (Kitab Undang-Undang Hukum Pidana) atau WvS (Wetboek van Strafrecht) dengan Misdrijven Tegen de Zeden. Ketentuan Pasal 281 sampai dengan Pasal 303 Kitab Undang-Undang Hukum Pidana (KUHP). Kesopanan dalam pengertian hukum pidana diartikan sinonimkan dengan kata kesusilaan (zeden, eebaarheid) yaitu perasaan malu yang berhubungan dengan nafsu kelamin misalnya berhubungan badan (bersetubuh), meraba atau meremas buah dada seorang perempuan, meraba atau mengelus atau memegang kemaluan perempuan, mempertontonkan anggota kemaluan seorang perempuan atau laki-laki, mencium dan sebagainya. Semuanya harus dengan perbuatan. Maka terhadap pelakunya 
diancam dan dipidana selama 2 (dua) tahun 8 (delapan) bulan penjara dan denda Rp 4500,(empat ribu lima ratus rupiah), sebagaimana ketentuan Pasal 281 KUHP (Kitab UndangUndang Hukum Pidana). ${ }^{39}$ Di samping itu, ada Pasal tentang perzinahan dengan ancaman pidana sembilan bulan (Pasal 284), Pasal tentang perkosaan dengan ancaman pidana selama dua belas tahun (Pasal 285), Pasal tentang bersetubuh dengan ancaman pidana sembilan tahun (Pasal 286), Pasal persetubuhan di bawah umur diancam dengan pidana sembilan tahun (Pasal 2687), Pasal perbuatan cabul dengan ancaman pidana sembilan tahun (Pasal 289), dan PasalPasal lainnya.

Di samping dengan perbuatan, ada juga diatur dengan perkataan, misal dengan katakata kemaluanmu mirip seperti ikan hiu, atau kemaluanmu seperti ikan asin. Hal tersebut dapat dikenakan ketentuan Pasal 315 KUHP (Kitab Undang-Undang Hukum Pidana), merupakan penghinaan ringan dengan ancaman pidana empat bulan dua minggu. ${ }^{40}$ Pembentuk Undang-Undang secara sengaja membuat dan mengatur tentang kejahatan terhadap kesusilaan dengan maksud untuk memberikan perlindungan terhadap orang-orang atas tindakan atau perbuatan asusila atau ontuchte handeligen dari perbuatan baik dalam bentuk lisan (kata-kata) atau perbuatan yang menyinggung perasaan susila. ${ }^{41}$ Salah satu peraturan perundangundangan yang memberikan perlindungan lebih bersifat khusus lagi Undang-Undang Nomor 11 Tahun 2008 tentang Informatika dan Transaksi Elektronik. Memberikan ancaman hukuman yang lebih berat terhadap kejahatan kesusilaan, penghinaan dan/atau pencemaran nama baik, pemerasan dan/atau pengancaman, ${ }^{42}$ diancam dengan pidana penjara paling lama 6 (enam) dan/atau denda satu milyar rupiah ${ }^{43}$, dan ancaman bagi kekerasan atau menakutnakuti yang ditujukan secara pribadi ${ }^{44}$ diancam dengan pidana paling lama 12 (dua belas) tahun dan/atau denda dua milyar rupiah. ${ }^{45}$ Korban terhadap kejahatan ini secara umum dialami oleh kaum perempuan.

Sedangkan dalam Peraturan Menteri Pendidikan dan Kebudayaan Nomor 30 Tahun 2021 tersebut, terhadap pelaku kekerasan seksual hanya berupa sanksi administratif berupa

\footnotetext{
${ }^{39}$ R. Soesilo, (1996), Kitab Undang-Undang Hukum Pidana (KUHP) Serta Komentar-Komentarnya Lengkap Pasal Demi Pasal, Bogor: Politeia, hal. 204.

${ }^{40}$ R.Soesilo,Ibid., 228.

${ }^{41}$ P.A.F. Lamintang, Theo Lamintang, (2009), Delik-Delik Khusus Kejahatan Peklanggaran Norma Kesusilaan Dan Norma Kepatutan, Edisi Kedua, Jakarta: Sinar Grafika, hlm. 1.

${ }^{42}$ Pasal 27 Undang-Undang Nomor 11 Tahun 2008 tentang Informatika dan Transaksi Elektronik.

${ }^{43}$ Pasal 29 Undang-Undang Nomor 11 Tahun 2008 tentang Informatika dan Transaksi Elektronik. Elektronik.

${ }^{44}$ Pasal 45 Ayat (1) Undang-Undang Nomor 11 Tahun 2008 tentang Informatika dan Transaksi Elektronik.
} 
sanksi administrasi ringan, sedang, dan berat. ${ }^{46}$ Teguran tertulis merupakan sanksi administrasi ringan dan pernyataan permohonan maaf secara tertulis yang dipublikasikan di internet media massa atau kampus. Pemberhentian sementara dari jabatan tanpa memperoleh hak jabatan dan bagi mahasiswa dikurangi haknya sebagai mahasiswa seperti: menunda perkuliahan (skors), beasiswa dicabut, dan dikurangi hak lainnya merupakan sanksi administrasi sedang, dan Pemberhentian tetap sebagai mahasiswa atau pemberhentian tetap dari jabatan sebagai pendidik (dosen), tenaga kependidikan (staf administrasi), warga kampus sesuai dengan peraturan perundang-undangan dari perguruan tinggi merupakan sanksi administrasi berat. ${ }^{47}$ Pemberian sanksi tersebut ternyata tidak mengesampingkan penjatuhan sanksi administrasi lainnya dan sanksi pidana sesuai dengan peraturan perundang-undangan yang berlaku. Pengaturan penjatuhan sanksi administrasi seperti itu sebenarnya setiap perguruan tinggi sudah memiliki statuta perguruan tinggi dan perangkat peraturan yang sengaja dibuat untuk mengatur segala aktifitas kegiatan perguruan tinggi.

\section{PENUTUP}

\section{Kesimpulan}

1. Upaya pengaturan antisipasi dan penyelesaian kekerasan seksual di perguruan tinggi berdasarkan Peraturan Menteri Pendidikan dan Kebudayaan Nomor 30 Tahun 2021 tentang Pencegahan dan Penanganan Kekerasan Seksual Di Lingkungan Perguruan Tinggi, yang menimbulkan polemik karena dianggap bertentangan dengan nilai-nilai agama antara lain: mempertontonkan alat kelamin secara sengaja tanpa ijin (persetujuan) korban, mengambil, merekam, dan/atau mengedarkan foto dan/atau rekaman audio dan/atau visual korban yang bernuasa seksual tanpa persetujuan korban, mengunggah foto tubuh dan/atau informasi pribadi korban yang berbau seksual tanpa ijin (persetujuan) korban, menyebarluaskan informasi yang ada hubungannya dengan tubuh dan/atau pribadi korban yang berbau seksual tanpa ijin (persetujuan) korban, menyentuh, mengusap, meraba, memegang, memeluk, mencium dan/atau menggosokkan bagian tubuh pada tubuh korban tanpa ijin (persetujuan) korban, melepas pakaian korban tanpa ijin (persetujuan) korban. Semua perbuatan tersebut apabila dilakukan dengan seijin (persetujuan) kedua belah pihak maka dianggap sah dan legal serta bukan termasuk

\footnotetext{
${ }^{46}$ Pasal 14 Ayat (1) Peraturan Menteri Pendidikan dan Kebudayaan Nomor 30 Tahun 2021 tentang Pencegahan dan Penanganan Kekerasan Seksual Di Lingkungan Perguruan Tinggi.

${ }^{47}$ Pasal 14 Ayat (2), (3), (4) Peraturan Menteri Pendidikan dan Kebudayaan Nomor 30 Tahun 2021 tentang Pencegahan dan Penanganan Kekerasan Seksual Di Lingkungan Perguruan Tinggi.
} 
kekerasan sebagaimana ketentuan Pasal 5 Ayat (1) Peraturan Menteri Pendidikan dan Kebudayaan tersebut.

2. Perspektif hukum terhadap Peraturan Menteri Pendidikan dan Kebudayaan Nomor 30 Tahun 2021 tentang Pencegahan dan Penanganan Kekerasan Seksual Di Lingkungan Perguruan Tinggi, menimbulkan polemik dan argumentasi yang berbeda di masyarakat. Argumentasi yang dibangun dalam peraturan menteri tersebut untuk berupaya melakukan pencegahan dan penanganan adanya kejahatan khususnya kekerasan seksual bagi mahasiswi di lingkungan kampus. Tetapi adanya frase “persetujuan Korban” justeru menabrak atau bertentangan nilai-nilai agama dan norma-norma di masyarakat karena menimbulkan pergaulan dan hubungan seks bebas yang dilakukan dengan dasar samasama suka. Pada akhirnya yang dirugikan adalah mahasiswi (perempuan).

\section{Saran}

1. Pembentuk undang-undang harus meninjau kembali atau merevisi Peraturan Menteri Pendidikan dan Kebudayaan Nomor 30 Tahun 2021 tentang Pencegahan dan Penanganan Kekerasan Seksual Di Lingkungan Perguruan Tinggi terhadap beberapa ketentuan yang dianggap bertentangan dengan nilai-nilai, norma-norma, dan ajaran agama khususnya Agama Islam, dan/atau dilakukan hak uji materiil atas Peraturan Menteri Pendidikan dan Kebudayaan tersebut kepada Mahkamah Agung Republik Indonesia baik melalui Pengadilan Negeri setempat dan/atau langsung kepada Mahkamah Agung Republik Indonesia.

2. Penegak hukum dan pemerintah harus tegas dalam menegakkan hukum terhadap pelaku kejahatan seksual khususnya yang terjadi di perguruan tinggi, agar menimbulkan efek jera bagi pelaku dan masyarakat, dan juga perempuan (mahasiswi) dapat menjaga dan mempertahankan harkat dan martabat sesuai dengan nilai-nilai, norma-norma, dan ajaran agama sehingga terhindar dari berbagai kejahatan termasuk kejahatan kekerasan seksual di lingkungan perguruan tinggi. 


\section{Buku}

\section{DAFTAR PUSTAKA}

Abdul Hamid, (2019), Rekonstruksi Tata Kelola Hakim Dalam Memeriksa Pelaku Tindak Pidana Anak Berbasis Nilai Keadilan, Disertasi, Program Doktor Ilmu Hukum Fakultas Hukum Universitas Islam Sultan Agung, Semarang: Unissula.

Departemen Pendidikan Nasional, (2005), Kamus Besar Bahasa Indonesia, Edisi Ketiga, Jakarta: Balai Pustaka.

P.A.F. Lamintang, Theo Lamintang, (2009), Delik-Delik Khusus Kejahatan Peklanggaran Norma Kesusilaan Dan Norma Kepatutan, Edisi Kedua, Jakarta: Sinar Grafika.

R. Soesilo, (1996), Kitab Undang-Undang Hukum Pidana (KUHP) Serta KomentarKomentarnya Lengkap Pasal Demi Pasal, Bogor: Politeia.

Peter Mahmud Marzuki, (2005), Penelitian Hukum, Surabaya: Kencana.

\section{Peraturan Perundang-Undangan}

Undang-Undang Dasar Negara Republik Indonesia Tahun 1945.

Undang-Undang Nomor 1 Tahun 1946 tentang Kitab Undang-Undang Hukum Pidana (KUHPidana).

Undang-Undang Nomor 8 Tahun 1981 tentang Kitab Undang-Undang Hukum Acara Pidana (KUHAP).

Undang-Undang Nomor 35 Tahun 2014 tentang Perubahan Atas Undang-Undang Nomor 23 Tahun 2002 tentang Perlindungan Anak.

Undang-Undang Nomor 39 Tahun 1999 tentang Hak Asasi Manusia.

Undang-Undang Nomor 12 Tahun 1995 tentang Lembaga Pemasyarakat.

Undang-Undang Nomor 11 Tahun 2008 tentang Informatika dan Transaksi Elektronik.

Kitab Undang-Undang Hukum Perdata KUHPerdata.

Peraturan Pemerintah Nomor 2 Tahun 1988 tentang Usaha Kesejahteraan Anak Bagi Anak yang Mempunyai Masalah.

Peraturan Presiden Republik Indonesia Nomor 25 Tahun 2005 tentang Komisi Nasional Anti Kekerasan Terhadap Perempuan.

Peraturan Menteri Pendidikan dan Kebudayaan Nomor 30 Tahun 2021 tentang Pencegahan dan Penanganan Kekerasan Seksual Di Lingkungan Perguruan Tinggi.

\section{Jurnal}


Jhon D. Pasalbessy, (2010), "Dampak Tindak Kekerasan Terhadap Perempuan dan Anak Serta Solusinya”, Jurnal Sasi, Volume 16, Nomor 3, Juli-September 2010.

Kurnia Muhajarah, (2016), "Kekerasan Terhadap Perempuan Dalam Rumah Tangga”, Jurnal Sawwa, Volume 11 Nomor 2, April 2016.

Maria Silvya E. Wangga, (2007), "Kekerasan Dalam Rumah Tangga Dan Usaha Merumuskan Familial Yang Demokratis", Jurnal Ilmu Hukum Universitas Islam Syekh Yusuf, Tangerang, 2007.

-----------, R. Bondan Agung Kardono, (2012) “Alternatif Penyelesaian Kekerasan Terhadap Perempuan", Adil: Jurnal hukum, Volume 9 Nomor 2, Tangerang, 2015.

Nurhayati, Y., Ifrani, I., Said, M.Y., (2021), "Metodologi Normatif dan Empiris Dalam Perspektif Ilmu Hukum, Jurnal Penegakan Hukum Indonesia”, Volume 2 Nomor 1, 1-20, https://doi.org/10.51749/jphi.v2iI.14.

Rissa Indrasty, Darajat Wibawa, Rojudin, (2018), “Gender Dalam Kasus Kekerasan Terhadap Perempuan Di Media Online", Jurnal Ilmu Jurnalistik, Volume 3 Nomor 1, Maret 2018.

Ruby Hadiarti Johny, (2011), “Tindak Pidana Kekerasan Terhadap Perempuan (Studi Etiologi Kriminal Di Wilayah Hukum Polres Banyumas)", Jurnal Dinamika Hukum, Volume 11 Nomor 2, 2 Mei 2011.

Umin Kango, (2009), "Bentuk Kekerasan Yang Dialami Perempuan”, Jurnal Legalitas, Volume 2 Nomor 1, Februari 2009.

Utami Zahirah Noviani P, Rifdah Afifah K, Cecep Sahadi Humaeni, (2018), "Mengatasi dan Mencegah Tindak Kekerasan Seksual Pada Perempuan Dengan Pelatihan Asertif’, Jurnal Penelitian dan PPM, Volume 5, Nomor 1, April 2018.

Venny Melisa Marbun, Randa Kristianta Purba, Rahmayanti, (2020), “Analisis Yuridis Terhadap Tindak Pidana Pelecehan Seksual Kepada Anak di Bawah Umur ", Adil Jurnal Hukum,, Volume 11, Nomor 1, 2020.

Yuni Kartika, Andi Najemi, (2020), "Kebijakan Hukum Perbuatan Pelecehan Seksual (Catcalling) Dalam Persepektif Hukum Pidana", Jurnal PAMPAS Journal of Criminal Law, Volume 1, Nomor 2, Juni 2020.

\section{Internet}

Tim Detik News, detikcom, https://newsdetik.com 